\title{
BULLETIN
}

\section{of the}

\section{AUSTRALIAN MATHEMATICAL SOCIETY}

\section{Volume 29 Number 3}

June 1984

Universally incomparable ring-homomorphisms

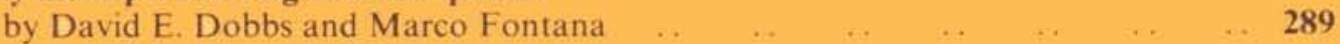

Algebras generated by symmetric idempotents

by David Choate..

Automorphism groups of orthomodular lattices

by Gudrun Kalmbach

A density problem for Hardy spaces of almost periodic functions

by Robyn Owens.

Univalent functions with univalent Gelfond-Leontev derivatives by O. P. Juneja and S. M. Shah.

Generalization of Leader's fixed point principle

by Tanmoy Som and R. N. Mukherjee

An integral characterization of Euclidean space

by J. M. Borwein ..

Monadic representability of certain binary relations

by $\mathrm{I}$. L. Humberstone

Oscillations in linear systems of differential-difference equations

Graphs with Eulerian chains

by Roger B. Eggleton and Donald K. Skilton

Free products of locally indicable groups with a single relator

by Benjamin Baumslag ...

Decompositions of graphs of modules over semisimple rings

by Grace Orzech ..

Cardinality of discrete subsets of a topological space: Corrigendum

by David B. Gauld and M. K. Vamanamurthy

ABSTRACTS OF ALSTRALASIAN PhD THESES

Epimorphisms and semigroup varieties

by Peter M. Higgins

Recursive properties of isomorphism types

by Michael Moses.

Composite graphs with stability index one

by K. L. McAvaney

Biordered sets of semigroups

by David Easdown.

Mathematical modelling of rate-limiting mechanisms of pyritic oxidation in overburden dumps

by Gregory Bruce Davis.. 


\section{BULLETIN OF THE AUSTRALIAN MATHEMATICAL SOCIETY}

Editor: Sidney A. Morris
Deputy Editor:

Honorary Editor:
K. R. Pearson

B. H. Neumann

\section{Associate Editors}

Robert S. Anderssen
Alan L. Andrew
B. D. Craven
Brian A. Davey
P. Donovan
J. A. Eccleston

Robert S. Anderssen

B. J. Gardner

J. R. Giles

J. R. J. Groves

J. A. Hempel

D. A. Holton

D. C. Hunt

\author{
P. E. Kloeden \\ Rodney Nillsen \\ Sheila Oates-Williams \\ A. J. van der Poorten \\ J. H. Rubinstein \\ Leon Simon
}

Ross Street

G. Szekeres

D. G. Tacon

Colin J. Thompson

H. B. Thompson

Rudolf Výborný

\section{Assistant Editors}

Robert S. Anderssen

M. S. Brooks

\section{INFORMATION FOR AUTHORS}

The BULLETIN of the Australian Mathematical Society aims at quick publication of original research in all branches of mathematics. Timely expository articles are also welcomed.

To ensure speedy publication, editorial decisions on acceptance or otherwise are taken quickly, normally within a month of receipt of the paper. Papers are accepted only after being evaluated by the Editor and an Associate Editor or another expert. Of course responsibility for the correctness of results published in the BULLETIN remains with the authors.

For a paper to be acceptable for publication, not only should it contain new and interesting results but also

(i) the exposition should be clear and attractive, and

(ii) the manuscript should be in publishable form, without revision.

Nevertheless some meritorious papers will have to be rejected because speed of publication involves space limitations.

Authors should submit THREE clean. high quality copies to

Dr S. Oates-Williams,

Department of Mathematics, University of Queensland,

St. Lucia, Queensland, 4067, Australia

but should not send the original typescript of their papers, as material submitted to the BULLETIN will usually not be returned. Authors should note that each paper submitted must include an abstract and one or more classification numbers following the 1980 Mathematics Subject Classification.

As even minor revisions are generally not permitted, authors should read carefully all the details listed on the inside back cover.

\section{Abstracts of PhD Theses}

The BULLETIN endeavours to publish abstracts of all accepted Australasian $\mathrm{PhD}$ theses in mathematics. One restriction, however, is that the abstract must be received by the Editor within 6 months of the degree being approved.

C) Copyright Statement. Where necessary. permission to photocopy for internal or personal use or the internal or personal use of specific clients is granted by the Treasurer, Australian Mathematical Publishing Association, Inc., for libraries and other uses registered with the Copyright Clearance Center (CCC). provided that the base fee of $\$ A 2.00$ per copy of article is paid directly to CCC. 21 Congress Street. Salem, MA 01970. U.S.A Special requests should be addressed to the Treasurer, Australıan Mathematical Publishing Association, inc. c/-Department of Mathematics, University of Queensland. St. Lucia, Qid. 4067. Australia. Serial-fee code: $0004.9727 / 84$ SA2.00 + 0.00 


\title{
BULLETIN \\ of the
}

ISSN 0004-9727

\section{Australian Mathematical Society}

\author{
Editor: Sidney A. Morris \\ Deputy Editor: K. R. Pearson \\ Honorary Editor: B. H. Neumann
}

\begin{tabular}{llll}
\multicolumn{4}{c}{ Associate Editors } \\
Robert S. Anderssen & B. J. Gardner & P. E. Kloeden & Ross Street \\
Alan L. Andrew & J. R. Giles & Rodney Nillsen & G. Szekeres \\
B. D. Craven & J. R. J. Groves & Sheila Oates-Williams D. G. Tacon \\
Brian A. Davey & J. A. Hempel & A. J. van der Poorten Colin J. Thompson \\
P. Donovan & D. A. Holton & J. H. Rubinstein & H. B. Thompson \\
J. A. Eccleston & D. C. Hunt & Leon Simon & Rudolf Výborný
\end{tabular}

Assistant Editors

Robert S. Anderssen

M. S. Brooks

\section{VOLUME 29 (1984)}


Printed by Watson Ferguson \& Co., Brisbane, Queensland 4101, Australia 


\section{Contents}

Vito Abatangelo, A translation plane of order 81 and its full collineation group $\quad$.

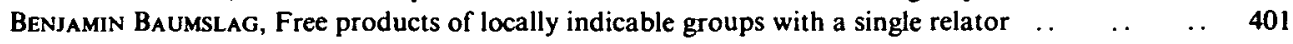

$\begin{array}{llllllll}\text { J. A. BEL WARD, Existence of solutions of Oseen type integral equations } & . . & \ldots & \ldots & \ldots & & \ldots & 57\end{array}$

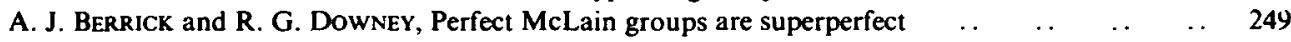

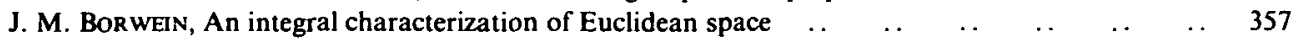

$\begin{array}{llllllllllll}\text { DAvid B. ChOATE, The density of subsequences.. } & . . & \ldots & \ldots & \ldots & \ldots & . . & . . & . & 145\end{array}$

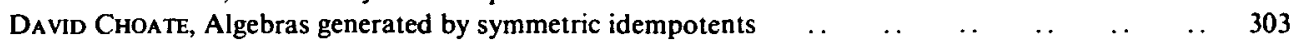

GREGory BrUCE DAVIs, Mathematical modelling of rate-limiting mechanisms of pyritic oxidation in

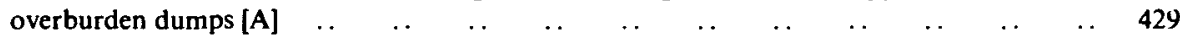

SATYa Deo and Dalip Singh JAmwal, Countable sum theorem for locally closed sets.. $\quad . \quad \quad$. $\quad 47$

M. Paul Devasahayam, Monotone method and periodic solution of non linear parabolic boundary

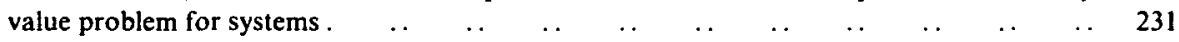

David E. DobBS and Marco Fontana, Universally incomparable ring-homomorphisms $\quad \ldots \quad$.. 289

R. G. DOWNEY, see A. J. BERRICK

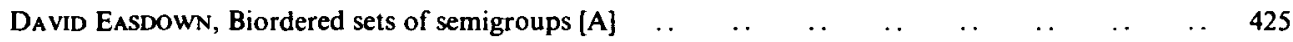

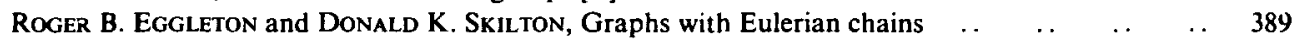

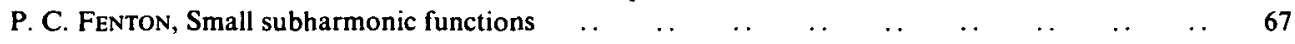

Marco Fontana, see David E. Dobbs

David B. Gauld and M. K. Vamanamurthy, Cardinality of discrete subsets of a topological space:

Corrigendum .

$\begin{array}{lllll}\text { K. Gopalsamy, Oscillations in linear systems of differential-difference equations . } & \text {.. } & \text {. . } & \text {. } & 377\end{array}$

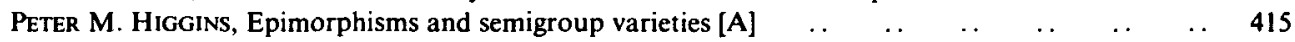

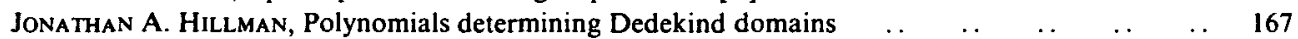

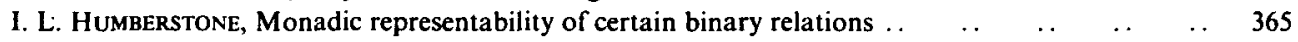

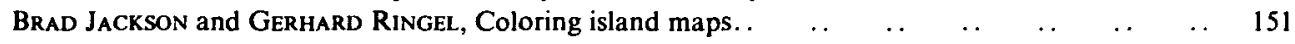

Dalip Singh Jamwal, see Satya Deo

O. P. JUNEJA and S. M. SHAH, Univalent functions with univalent Gelfond-Leontev derivatives $\quad . \quad 329$

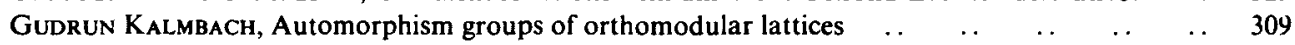

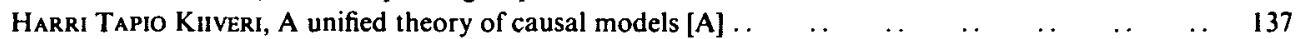

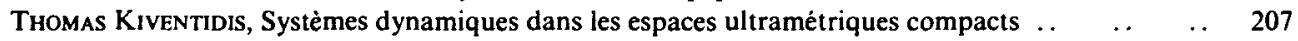

Thomas Kiventidis, Comparaison resultats pour la stabilité pratique $\quad$.

$\begin{array}{lllll}\text { J. H. Loxton, A method of Mahler in transcendence theory and some of its applications } & \ldots & \ldots & 127\end{array}$

$\begin{array}{llllllllll}\text { KURT MAHLER, Some suggestions for further research. . } & \text {. } & \ldots & \ldots & \ldots & \text {. } & \text {.. } & \text {. } & 101\end{array}$

J. J. MALONE, $p$-groups with non-abelian automorphism groups and all automorphisms central $\quad . \quad 35$

R. M. M. MATTHEIJ, The stability of LU-decompositions of block tridiagonal matrices. $\quad$.. $\quad$.. 177

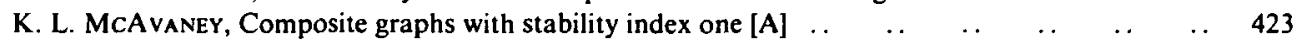

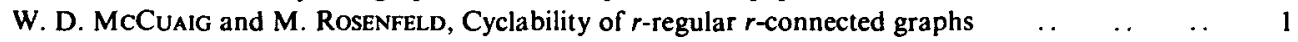

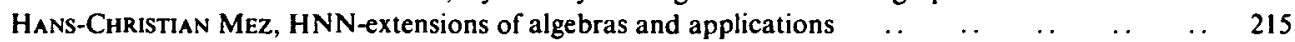

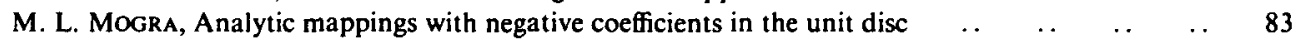

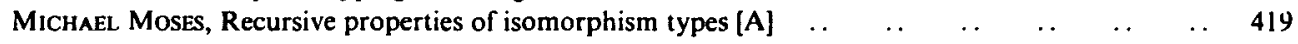

R. N. MuKhERJEe, see TANMOY SOM

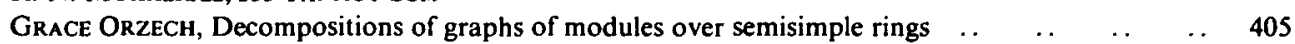

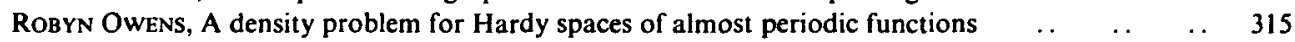

A. J. VAN DER POORTEN, $p$-adic methods in the study of Taylor coefficients of rational functions $\quad . . \quad 109$

Govind Prasad, see Ashok Sahal

M. Rama Mohana RaO and P. SRINIVAs, Stability of functional differential equations of Volterra type 93

Gerhard Ringel, see Brad Jackson

M. ROSENFELD, see W. D. MCCuAIG

Ashok Sahai and Govind Prasad, Sharp estimates of approximation by some positive linear operators 
S. M. Shah, see O. P. Juneja

Donald K. Skilton, see Roger B. Eggleton

TANmoY SOM and R. N. MUKhERJEe, Generalization of Leader's fixed point principle .. $\quad \ldots \quad \ldots \quad 349$

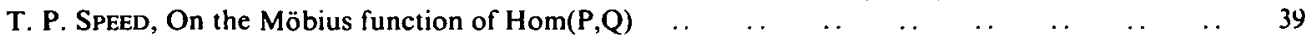

P. Srinivas, see M. Rama Mohana Rao

Cezary S. Surma, Discrete Green's functions and random resistive networks [A] $\quad \ldots \quad$. $\quad \ldots \quad 139$

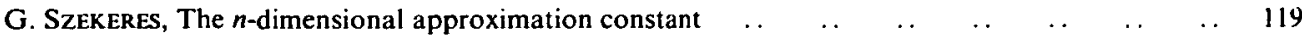

VIDAR THOMÉE, The finite difference versus the finite element method for the solution of boundary value problems

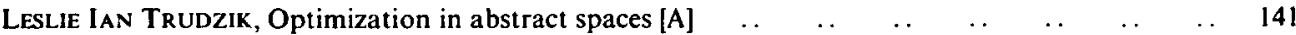

M. K. Vamanamurthy, see David B. Gauld

V. ZIZLER, Locally uniformly rotund renorming and decompositions of Banach spaces . $\quad \ldots \quad$. $\quad 259$

[A] Abstract of Australasian PhD thesis. 